\title{
UPAYA PENGOLAHAN LIMBAH KOTORAN BABI MENJADI KOMPOS MENGGUNAKAN KOMPOSTER RUMAH TANGGA
}

\author{
Ni Luh Widyasari ${ }^{1 *)}$, I Wayan Budiarsa Suyasa ${ }^{2)}$, I.G.B Sila Dharma ${ }^{3)}$ \\ ${ }^{1)}$ Program Magister Ilmu Lingkungan Universitas Udayana \\ ${ }^{2)}$ FakultasMatematika dan Ilmu Pengetahuan Alam Universitas Udayana \\ ${ }^{3)}$ Fakultas Kelautan dan Perikanan Universitas Udayana \\ *Email: ms_widya91@yahoo.com
}

\section{ABSTRACT \\ EFFORTS TO PROCESS PIG MANURE WASTE INTO THE COMPOST USING HOUSEHOLD COMPOSTER}

The production of pig manure waste potentially pollutes the soil, water and air. One of the most effective processing a waste treatments is through composting. The composting process takes a long time if not assisted by the activator as decomposers of organic materials in order to accelerate the composting process. Activators such as local microorganism (MOL) contain macro nutrients, micro and active microorganism that potentially decomposed organic materials, growth stimulants and pest/disease control agents such as to help speed up the composting process. This study aims to determine the $\mathrm{C} / \mathrm{N}$ ratio of optimal raw materials for composting of pig manure and vegetable waste, determining the effect of adding local microorganism (MOL) to the length of time of composting and determining the effectiveness of business from composting of pig manure and vegetable waste based on the calculation of $\mathrm{B} / \mathrm{C}$ ratio.

This research uses quantitative approach with experiment method. The first stage is the preparation of the raw material which is divided into three groups: composition 1 with $75 \%$ (pig manure) and 25\% (vegetable waste), composition 2 with $50 \%$ (pig manure) and 50\% (vegetable waste) and then composition 3 with 25\% (pig manure) and $75 \%$ (vegetable waste). Furthermore, the best raw material composition was treated with variations of MOL addition of A $(100 \mathrm{ml}), \mathrm{B}(300 \mathrm{ml}), \mathrm{C}(500 \mathrm{ml})$ and D (without MOL).

The results showed that the composition of the best raw material mixture was a mixture composition of $25 \%$ (pig manure) and $75 \%$ (vegetable waste) with a $\mathrm{C} / \mathrm{N}$ ratio of 38.95. The effect of MOL addition indicates that the greater MOL volume the faster to composting process. The quality compost with addition of MOL has $\mathrm{C} / \mathrm{N}$ ratio levels is $(16,30)$, N-total $(1,65 \%)$, $\mathrm{P}$ tersedia $(8043,02 \mathrm{ppm}), \mathrm{K}$ tersedia (8857,40 ppm), Fe (1,87\%), Mn (0,09\%) Zn (480 ppm)in which thatvalue meets the SNI 19-7030-2004. Based on analysis of $\mathrm{B} / \mathrm{C}$ ratio obtained result of 1.04 where the value is approaching criteria $\mathrm{B} / \mathrm{C}$ ratio more than 1.00 which means compost business feasible to be developed.

Keywords: Pig manure, MOL, time of composting, composter, $\mathrm{B} / \mathrm{C}$ ratio 


\section{PENDAHULUAN}

Usaha ternak babi menjadi salah satu komoditas peternakan yang sangat potensial di Bali. Berdasarkan data Badan Pusat Statistik Kota Denpasar tahun 2015, jumlah populasi babi di kota Denpasar adalah 13.729 ekor. Populasi ternak babi menempati urutan kedua setelah populasi ternak ayam yang berada di urutan pertama. Berkembangnya usaha ternak babi memberikan keuntungan cukup besardan menjadi sumberpendapatan bagi masyarakat. Namun demikian,usaha ternak juga menghasilkan limbahyang menjadi sumber pencemaran lingkungan.

Limbah peternakan babi terdiri dari dua jenis yaitu padat dan cair. Limbah padat berupa kotoran sedangkan limbah cair berupa urin. Limbah kotoran hewan ternak sangat berpotensi sebagai sumber pupuk organik (Widjajanto dan Sumarsono, 2005; Sihombing, 2006). Kotoran babi kaya akan unsur nitrogen sehingga dapat digunakan sebagai bahan baku kompos. Kandungan unsur kalium pada kotoran babi dua kali lebih tinggi dibandingkan kotoran sapi dan kambing (Sihombing, 2006). Nitrogen dan kalium sangat diperlukan oleh tanaman sebagai perangsang pertumbuhan tanaman serta memperlancar proses fotosintesis.

Proses pengomposan membutuhkan waktu yang cukup lama apabila tidak dibantu dengan aktivator sebagai pengurai bahan organik guna mempercepat berlangsungnya proses pengomposan. Aktivator berupa mikroorganisme lokal (MOL) dapat diperoleh dari limbah organik seperti limbah sayur dan buah busuk melalui proses fermentasi. Larutan MOL mengandung unsur hara makro, mikro dan mikroorganisme aktif yang berpotensi sebagai pengurai bahan organik, perangsang pertumbuhan, dan agen pengendali hama dan penyakit sehingga dapat membantu mempercepat proses pengomposan (Purwasasmita dan Kunia, 2009).

Penggunaan pupuk organik sangat penting sebagai penyangga sifat fisik, kimia, dan biologi tanah sehingga dapat meningkatkan efisiensi pupuk dan produktivitas lahan. Penelitian Waris dan Achmar (2015)menyatakan bahwa Desa Sumber Anyar, Kecamatan Mlandingan, Kabupaten Situbondo menjadi desa yang mengembangkan usaha pembuatan kompos. Kelayakan usaha pembuatan kompos oleh kelompok petani di Desa Sumber Anyar, ditetapkan berdasarkan analisis B/C rasio. Nilai $\mathrm{B} / \mathrm{C}$ rasio sebesar 3,05 menunjukkan bahwa usaha pembuatan kompos di Desa Sumber Anyar layak dikembangkan dan mampu memberikan penghasilan cukup baik bagi para petani. Produksi kompos dari kotoran babi dan limbah sayuranjuga berpotensi untuk dikembangkan. Oleh karena itu, perlu dilakukan analisis $\mathrm{B} / \mathrm{C}$ rasio untuk membuktikan bahwa pembuatan kompos kotoran babi dan limbah sayuranlayak untuk dikembangkan oleh para petani.

Berdasarkan hal tersebut menimbulkan ide untuk melakukan upaya pengolahan limbah kotoran babi menjadi kompos. Tujuan penelitian ini adalah (1) untuk menentukan $\mathrm{C} / \mathrm{N}$ rasio optimal bahan baku untuk pembuatan kompos kotoran babi dan limbah sayuran (2) untuk menentukan pengaruh penambahan mikroorganisme lokal (MOL)terhadap lama waktu proses pembuatan kompos kotoran babi dan limbah sayuran (3) untuk menentukan kualitas kompos kotoran babi dan limbah sayuran dengan penambahan MOL (4) untuk menentukan kelayakan usaha pembuatan kompos kotoran babi dan limbah sayuran berdasarkan perhitungan $\mathrm{B} / \mathrm{C}$ rasio. 


\section{METODOLOGI}

\subsection{Lokasi dan Waktu Penelitian}

Penelitian dilaksanakan di peternakan babi skala rumah tangga milik Ibu Iluh dan Ibu Parmi beralamat di Jalan Kresek Gang Lumba-Lumba IV No.2, Kelurahan Sidakarya, Kecamatan Denpasar Selatan. Penelitian ini berlangsung dari bulan Mei hingga September yang terbagi dalam tiga tahap yaitu tahap pertama adalah persiapan bahan dan analisis $\mathrm{C} / \mathrm{N}$ rasio bahan di laboratorium pada bulan Mei, tahap kedua adalah proses komposting berlangsung dari bulan Juni hingga Agustus dan tahap ketiga adalah analisis sampel kompos berlangsung dari bulan Agustus hingga September yang dilakukan di Laboratorium Tanah Fakultas Pertanian Universitas Udayana.

\subsection{Prosedur Penelitian}

\subsubsection{Tahap Awal Penelitian}

Tahap awal sebelum proses komposting adalah penyiapan bahan baku kompos meliputi kotoran babi, limbah organik sayuran terdiri dari kol, bayam, sawi, kangkung dan mentimun. Bahan baku akan dikelompokkan dalam tiga kelompok terdiri dari:

K1: $75 \%$ kotoran babi $+25 \%$ limbah sayuran

K2: $50 \%$ kotoran babi $+50 \%$ limbah sayuran

K3: $25 \%$ kotoran babi $+75 \%$ limbah sayuran

Masing-masing bahan baku dicampur kemudian sampelnya diambil sebanyak 100 gram dan dilakukan uji $\mathrm{C} / \mathrm{N}$ rasio di Labortaorium Tanah Fakultas Pertanian UNUD.

\subsubsection{Tahap Perlakuan}

Komposisi bahan baku dengan $\mathrm{C} / \mathrm{N}$ rasio terbaik pada uji tahap sebelumnya lalu diberi perlakuan dengan menambahkan larutan MOLyang dibagi menjadi empat formulasi yaitu

A : campuran bahan baku $+100 \mathrm{ml}$ MOL

B : campuran bahan baku $+300 \mathrm{ml}$ MOL

$\mathrm{C}$ : campuran bahan baku $+500 \mathrm{ml}$ MOL

D : campuran bahan baku tanpa MOL

Sebelumnya, MOL diencerkan dengan air hingga mencapai volume 2 liter kemudian larutan MOL disemprot ke bahan baku kompos yang ditempatkan pada komposter. Perlakuan dengan penambahan MOL bertujuan untuk mengetahui lama waktu pengomposan berlangsung sampai kompos menjadi matang.

\subsubsection{Pengujian Parameter Fisik dan Kimia Kompos}

Parameter fisik kompos yang diukur serta diamati antara lain perubahan suhu, warna dan bau tumpukan kompos selama proses pengomposan setiap tiga hari sekali sampai kompos menjadi matang.Selanjutnya dihitung lama waktu proses pengomposan pada masingmasing sampel A, B, C, D. Parameter kimia kompos meliputi $\mathrm{pH}, \mathrm{C} / \mathrm{N}$ rasio, unsur hara makro $(\mathrm{N}, \mathrm{P}, \mathrm{K})$ dan unsur hara mikro (Fe, Mn, Zn) diuji di Labortaorium Tanah Fakultas Pertanian UNUD.

\section{HASIL DAN PEMBAHASAN}

\subsection{Analisis $\mathrm{C} / \mathrm{N}$ Rasio Bahan Baku Kompos}

Nilai C/N rasio pada ketiga sampel yaitu $\mathrm{K} 1$, K2 dan $\mathrm{K} 3$ diperoleh dengan membandingkan kadar C-organik dan $\mathrm{N}$ total masing-masing sampel. Perhitungan ketiga sampel tentu memiliki nilai $\mathrm{C} / \mathrm{N}$ rasio yang berbeda. Sampel K1 memiliki kadar C-organik $19,48 \%$ dan $\mathrm{N}$ total $0,10 \%$ sehingga diperoleh nilai C/N rasio sebesar 194,80. Sampel K2 memiliki kadar C-organik 
$19,48 \%$ dan $\mathrm{N}$ total sebesar $0,44 \%$ sehingga diperoleh nilai $\mathrm{C} / \mathrm{N}$ rasio sebesar 44,27 sedangkan sampel K3 memiliki kadar C-organik sebesar $15,58 \%$ dan $\mathrm{N}$ total $0,40 \%$ sehingga diperoleh nilai $\mathrm{C} / \mathrm{N}$ rasio sebesar 38,95. Nilai $\mathrm{C} / \mathrm{N}$ rasio ketiga komposisi bahan baku kompos dapat dilihat dalam bentuk grafik pada Gambar 1.

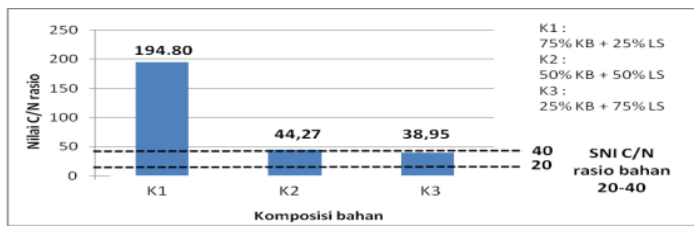

Gambar 1.

Grafik pengaruh komposisi campuran bahan baku kompos terhadap $\mathrm{C} / \mathrm{N}$ rasio

Komposisi pertama (K1) memiliki tingkat $\mathrm{C} / \mathrm{N}$ rasio 194,80 dimana nilainya paling tinggi diantara komposisi kedua (K2) 44,27 dan komposisi ketiga (K3) 38,95. Tingginya $\mathrm{C} / \mathrm{N}$ rasio tersebut disebabkan oleh kadar Corganik lebih besar dibandingkan kadar $\mathrm{N}$ total pada bahan baku. Campuran bahan baku K1 memiliki volume kotoran babi lebih besar dibandingkan dengan volume limbah sayuran. Kotoran babi memiliki kandungan karbon cukup tinggi dikarenakan jenis pakan babi yang dikonsumsi seperti sayur sayuran, dedak, ampas tahu, limbah rumah tangga dan konsentrat yang kaya akan karbohidrat. Hal ini terbukti dengan hasil analisis bahwakadar C-organik pada campuran bahan baku K1 lebih besar dibandingkan kadar $\mathrm{N}$ total.

Berbeda dengan nilai $\mathrm{C} / \mathrm{N}$ rasio pada K1, sebaliknya komposisi bahan baku ketiga (K3) memiliki nilai $\mathrm{C} / \mathrm{N}$ rasio paling rendah yaitu 38,95 . Hal ini disebabkan komposisi campuran bahan baku yang lebih didominasi oleh volume limbah sayuran sebesar $75 \%$ dibandingkan kotoran babi 25\%. Limbah sayuran seperti bayam dan kangkung kaya akan kandungan protein, mineral dan serat yang mampu mengikat karbon berlebih pada kotoran babi sehingga kadar C-organik bahan baku K3 tidak terlalu tinggi. Perbandingan $\mathrm{C} / \mathrm{N}$ rasio $\mathrm{K} 3$ termasuk dalam perbandingan ideal dimana kadar C-organik dan $\mathrm{N}$ total menghasilkan nilai $\mathrm{C} / \mathrm{N}$ rasio lebih rendah dibandingkan campuran bahan baku K1.

Tingkat kematangan kompos dan lama proses pengomposan ditentukan oleh nilai $\mathrm{C} / \mathrm{N}$ rasio bahan organik kompos. Tingkat $\mathrm{C} / \mathrm{N}$ rasio tinggimenyebabkan proses dekomposisi semakin lama, sedangkan tingkat $\mathrm{C} / \mathrm{N}$ rasio rendah akan mempercepat proses dekomposisi. Menurut Rynk, et. al (1992), standar $\mathrm{C} / \mathrm{N}$ rasio bahan baku kompos adalah 20-40. Oleh karena itu, komposisi campuran bahan baku sampel K3 terdiri dari $25 \%$ kotoran babi dan $75 \%$ limbah sayuran dengan $\mathrm{C} / \mathrm{N}$ rasio sebesar 38,95 merupakan komposisi campuran yang tepat digunakan sebagai komposisi campuran bahan baku pembuatan kompos.

\subsection{Analisis Fisik Kompos 3.2.1. Suhu Kompos}

Pengamatan suhu dilakukan untuk mengetahui perubahan aktivitas mikroorganisme saat proses pengomposan berlangsung. Proses pengomposan mengalami tiga tahap perubahan suhu yaitu mesofilik, termofilik dan pendinginan (Darius, 2001). Perubahan suhu dalam proses pengomposan dapat dilihat pada Gambar2.

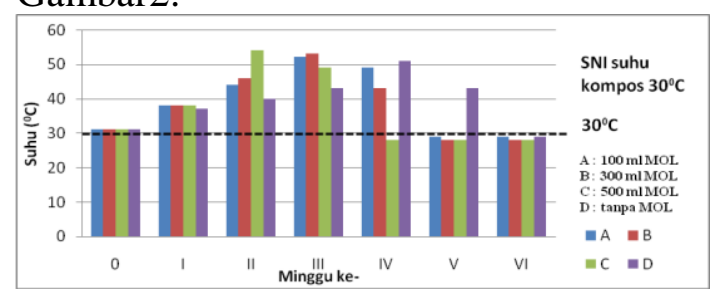

Gambar 2.

Grafik perubahan suhu selama proses pengomposan 
Gambar 3.2 menunjukkan grafik perubahan suhu dari hari pertama pengomposan yaitu awal proses dekomposisi, oksigen dan senyawa yang mudah terdegradasi akandimanfaatkan oleh mikroorganisme mesofilik dimana keempatperlakuan memiliki suhu ratarata $31^{\circ} \mathrm{C}$.Suhu awal tersebut membuktikan bahwaproses pengomposan dimulai dengan proses mesofilik yang memiliki temperatur berkisar antara $25-45^{\circ} \mathrm{C}$.

Setelah mengalami fase mesofilik, minggu berikutnya tumpukan kompos akan mengalami fase termofilik dimana penambahan aktivator berupa larutan MOL menjadikan mikroorganisme yang terdapat dalam tumpukan bahan kompos menjadi lebih aktif. Aktivitas mikroorganisme inilah yang menyebabkan suhu tumpukan bahan kompos mengalami peningkatan. Setelah melalui fase termofilik mengalami penurunan suhu dan $\mathrm{pH}$ maka digantikan dengan fase pendinginan serta diikuti fase pematangan kompos.

Hasil pengamatan perubahan suhu pada keempat perlakuan menunjukkan bahwa penambahan MOL memberikan pengaruh nyata terhadap kenaikan suhu serta lama proses pengomposan berlangsung. Perlakuan $\mathrm{C}$ menjadi perlakuan yang paling cepat mengalami proses pematangan kompos dalam waktu 4 minggu. Sementara perlakuan D menjadi perlakuan paling lama mengalami proses pematangan kompos dengan kurun waktu 6 minggu.

\subsubsection{Warna Kompos}

Perubahan warna kompos tergantung dari campuran bahan baku yang digunakan. Menurut Hsieh (1990), mengelompokkan tingkat kematangan kompos dalam tiga kategori yaitu 1) kompos belum matang memiliki warna dan bentuk seperti aslinya yaitu kuning kehijauan, 2) kompos matang sebagia memiliki perubahan warna menjadi kecokelatan, tetapi masih terlihat bentuk aslinya dan tidak mudah dihancurkan apabila digesek dengan jari, 3) kompos matang memiliki warna coklat kehitaman yang menyerupai warna tanah. Hasil pengamatan warna kompos dapat dilihat pada Tabel 1 .

Tabel 1.Pengamatan perubahan warna kompos selama proses pengomposan

\begin{tabular}{|c|c|c|c|c|c|c|}
\hline \multirow{2}{*}{ Perlakuan } & \multicolumn{7}{|c|}{ Minggu ke- } \\
\cline { 2 - 7 } & $\mathbf{1}$ & $\mathbf{2}$ & $\mathbf{3}$ & $\mathbf{4}$ & $\mathbf{5}$ & $\mathbf{6}$ \\
\hline $\begin{array}{c}\mathrm{A}(100 \mathrm{~mL} \\
\text { MOL) }\end{array}$ & $\mathrm{H}$ & $\mathrm{H}$ & $\mathrm{C}$ & $\mathrm{C}$ & $\mathrm{CK}$ & $\mathrm{CK}$ \\
\hline $\begin{array}{c}\mathrm{B}(300 \mathrm{~mL} \\
\text { MOL) }\end{array}$ & $\mathrm{H}$ & $\mathrm{H}$ & $\mathrm{C}$ & $\mathrm{CK}$ & $\mathrm{CK}$ & $\mathrm{CK}$ \\
\hline $\begin{array}{c}\text { C (500 mL } \\
\text { MOL) }\end{array}$ & $\mathrm{H}$ & $\mathrm{C}$ & $\mathrm{CK}$ & $\mathrm{CK}$ & $\mathrm{CK}$ & $\mathrm{CK}$ \\
\hline $\begin{array}{c}\text { D (tanpa } \\
\text { MOL) }\end{array}$ & $\mathrm{H}$ & $\mathrm{H}$ & $\mathrm{H}$ & $\mathrm{C}$ & $\mathrm{C}$ & $\mathrm{CK}$ \\
\hline
\end{tabular}

Keterangan : Hijau $=\mathrm{H}$, Cokelat $=\mathrm{C}$, Cokelat kehitaman $=\mathrm{CK}$

Hasil pengamatan menunjukkan perubahan warna kompos pada masingmasing perlakuan berbeda. Pada perlakuan A perubahan warna asli berubah menjadi cokelat di minggu ke-3 selanjutnya di minggu ke-5 warna kompos berubah menjadi cokelat kehitaman yang menandakan bahwa kompos sudah matang.

Perlakuan B memiliki proses pematangan yang hampir sama dengan perlakuan A namun, perubahan warna kompos matang lebih cepat terjadi yaitu di minggu ke-4. Perlakuan $\mathrm{C}$ memiliki tingkat proses pematangan paling cepat diantara perlakuan $\mathrm{A}$ dan $\mathrm{B}$, dimana perubahan warna kompos matang terjadi di minggu ke-3 dari cokelat menjadi cokelat kehitaman.

Perlakuan D memiliki tingkat proses kematangan paling lambat diantara perlakuan A, B dan C. Perubahan warna cokelat menjadi cokelat kehitaman terjadi di minggu ke-6. Hal ini disebabkan oleh jumlah mikroorganisme 
yang sedikit dalam merombak bahan organik sehingga proses pengomposan berlangsung lama. Pada perlakuan A, B dan $\mathrm{C}$ proses pematangan kompos berlangsung lebih cepat karena adanya penambahan larutan MOL yang mengandung mikroorganisme yang membantu perombakan bahan organik. Perlakuan $\mathrm{C}$ dengan penambahan larutan MOL sebesar $500 \mathrm{ml}$ memiliki tingkat kematangan paling cepat diantara semua perlakuan yaitu pada minggu ke-3.

\subsubsection{BauKompos}

Bau atau aroma yang dihasilkan pada proses pengomposan menandakan bahwa terjadi aktivitas dekomposisi bahan oleh mikroorganisme. Pengamatan baupada komposdilakukan menggunakan indra penciuman,kemudian dilakukan pencatatan dalam bentuk tabel dengan tiga kriteria bau pada bahan baku. Padatabel 2 disajikan perubahan bau/ aroma kompos dari tahap awal pengomposan hingga akhir pengomposan.

Tabel 2.Perubahan bau kompos selama proses pengomposan

\begin{tabular}{|c|c|c|c|c|c|c|}
\hline \multirow{2}{*}{ Perlakuan } & \multicolumn{6}{|c|}{ Minggu ke- } \\
\hline & 1 & 2 & 3 & 4 & 5 & 6 \\
\hline $\begin{array}{c}\text { A }(100 \mathrm{~mL} \\
\text { MOL) }\end{array}$ & + & + & ++ & ++ & +++ & +++ \\
\hline $\begin{array}{c}\mathrm{B}(300 \mathrm{~mL} \\
\text { MOL) }\end{array}$ & + & + & ++ & +++ & +++ & +++ \\
\hline $\begin{array}{c}\mathrm{C}(500 \mathrm{~mL} \\
\text { MOL) }\end{array}$ & + & ++ & +++ & +++ & +++ & +++ \\
\hline $\begin{array}{c}\text { D (tanpa } \\
\text { MOL) }\end{array}$ & + & + & + & ++ & ++ & +++ \\
\hline \multicolumn{2}{|c|}{ Keterangan: } & $\begin{array}{l}+ \\
++ \\
++\end{array}$ & $=$ & be & bau & $\begin{array}{l}\text { si } \\
\text { at }\end{array}$ \\
\hline
\end{tabular}

tanah

Tabel2 menunjukkan bahwa bau/aroma dari kompos pada perlakuan A menghasilkan bau asli di minggu ke-1 dan ke-2 kemudian di minggu ke-3 dan ke-4 bau tumpukan kompos sangat menyengat. Hal ini disebabkan oleh proses perombakan bahan kompos oleh mikroorganisme yang melepaskan gas $\mathrm{NH}_{3}$, air dan panas ke udara sehingga bau pada tumpukan bahan kompos sangat menyengat. Pada minggu ke-5 bau menyengat berkurang dan secara perlahan bau tumpukan bahan kompos berubah seperti tanah menunjukkan bahwa kompos mengalami proses pematangan.

Pada perlakuan B proses pematangan terjadi di minggu ke-4 sedangkan perlakuan $\mathrm{C}$ mengalami proses pematangan lebih cepat yaitu di minggu ke-3. Hal ini disebabkan oleh perbedaan volume penambahan larutan MOL pada masing-masing perlakuan. Perlakuan $\mathrm{C}$ dengan penambahan larutan MOL lebih banyak dari perlakuan A dan B mengalami proses pematangan lebih cepat karena jumlah mikroorganisme yang bekerja pada tumpukan kompos lebih banyak dan aktif merombak bahan lebih cepat. Berbeda dengan perlakuan D tanpa larutan MOL yang mengalami proses pematangan lebih lama dari perlakuan A, B dan C. Proses pematangan terjadi di minggu ke-6. Hal ini disebabkan oleh aktivitas mikroorganisme yang jumlahnya sedikit sehingga proses perombakan bahan organik kompos berlangsung dalam jangka waktu lebih lama.

\subsection{Analisis Kimia Kompos}

\subsubsection{Analisis C/N Rasio Kompos}

Hasil analisis $\mathrm{C} / \mathrm{N}$ rasio kompos menunjukkan bahwa penambahan MOL tidak berpengaruh terhadap nilai $\mathrm{C} / \mathrm{N}$ rasio kompos. Semua perlakuan mengalami penurunan $\mathrm{C} / \mathrm{N}$ rasio dari nilai awal 38,95 menjadi 11,89 pada perlakuan A dengan penambahan $100 \mathrm{ml}$ MOL. Pada perlakuan B dengan penambahan $300 \mathrm{ml}$ MOL turun menjadi 14,31 dilanjutkan pada perlakuan $\mathrm{C}$ dengan penambahan $500 \mathrm{ml}$ MOL nilai 
$\mathrm{C} / \mathrm{N}$ rasio turun menjadi 16,30 . Pada perlakuan $\mathrm{D}$ tanpa penambahan MOL mengalami penurunan rata-rata $\mathrm{C} / \mathrm{N}$ rasio menjadi 17,31. Perlakuan D merupakan campuran bahan baku yang terdiri dari kotoran babi dan limbah sayuran tanpa tambahan aktivator berupa MOL. Peran aktif MOL adalah menurunkan kadar $\mathrm{C} / \mathrm{N}$ rasio bahan baku sehingga proses pengomposan dapat berlangsung lebih cepat. Pada perlakuan $\mathrm{D}$, cenderung memiliki kadar $\mathrm{C} / \mathrm{N}$ rasio tinggi dikarenakan perlakuan tersebut tidak menggunakan MOL dalam proses pengomposan sehingga penurunan kadar $\mathrm{C} / \mathrm{N}$ rasio tidak optimal. Perlakuan $\mathrm{A}, \mathrm{B}$ dan $\mathrm{C}$ memiliki nilai $\mathrm{C} / \mathrm{N}$ rasio lebih rendah dari perlakuan D. Hal ini disebabkan penambahan MOL pada perlakuan A, B dan C mampu menurunkan $\mathrm{C} / \mathrm{N}$ rasio bahan secara optimal dengan bantuan mikroorganisme aktif sehingga proses pengomposan berlangsung lebih cepat. Nilai $\mathrm{C} / \mathrm{N}$ rasio dari keempat perlakuan dapat dilihat pada grafik Gambar 3.

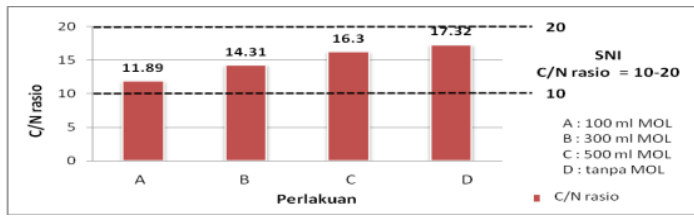

Gambar 3.

Grafik nilai $\mathrm{C} / \mathrm{N}$ rasio perlakuan $\mathrm{A}, \mathrm{B}$, C, D

\subsubsection{Analisis Unsur Hara Makro (N, P, K)Kompos}

Hasil analisis kandungan makro pada kompos meliputi nitrogen ( $\mathrm{N}$ total), phosfor $\left(\mathrm{P}_{2} \mathrm{O}_{5}\right)$ dan kalium $\left(\mathrm{K}_{2} \mathrm{O}\right)$ pada empat perlakuan dapat dilihat pada grafik Gambar 4 dan 5. Gambar 4 menunjukkan kadar nitrogen total yang terdapat dalam kompos kotoran babi dan limbah sayuran. Hasil analisis dalam grafik menunjukkan perlakuan $\mathrm{A}$ memiliki kadar nitrogen sebesar 2,10\% kemudian diikuti oleh perlakuan B yang memiliki kandungan nitrogen sebesar $2,03 \%$, perlakuan $\mathrm{C}$ sebesar $1,95 \%$ dan yang paling rendah adalah perlakuan D tanpa aktivator sebesar $1,79 \%$. Keempat perlakuan menunjukkan nilai di atas standar SNI 19-7030-2004 yaitu $>0,40 \%$. Tersedianya unsur nitrogen dalam jumlah tinggi disebabkan oleh bahan baku utama kompos yaitu kotoran babi yang mengandung nitrogen cukup tinggi dan limbah sayuran juga kaya akan kandungan nitrogen sehingga komposisi bahan baku kompos yang menyebabkan tingginya kadar nitrogen pada kompos. Nitrogen mengambil peran penting dalam merangsang pertumbuhan vegetatif tanaman.

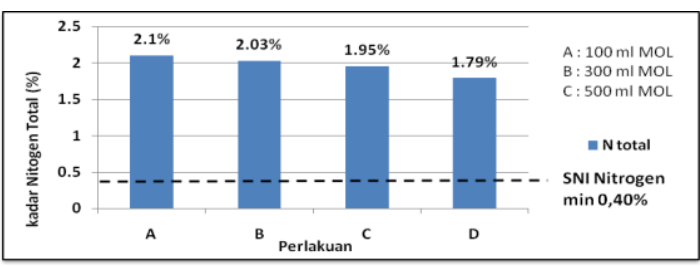

Gambar 4.

Grafik analisis kadar Nitrogen Total Kompos

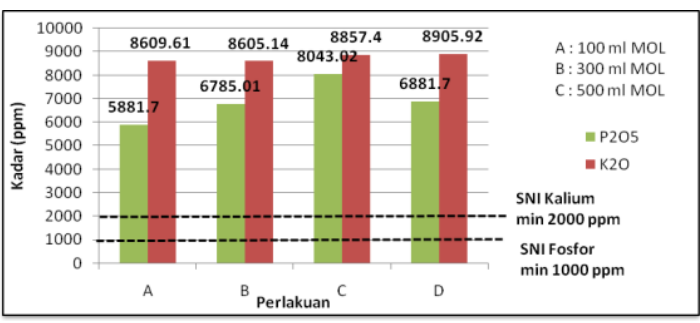

Gambar 5.

Grafik analisis unsur hara makro Fosfor dan Kalium Kompos

Gambar 5 menunjukkan grafik unsur hara makro fosfor yang memiliki peran penting bagi tanaman dalam hal proses fotosintesis, respirasi dan penyimpanan energi. Hasil analisis menunjukkan kadar fosfor paling tinggi diperoleh pada perlakuan A sebesar 5881,70 ppm diikuti oleh perlakuan B 6785,01 ppm lalu paling rendah pada perlakuan C 8043,02 ppm dan perlakuan 
D sebesar 6881,70 ppm. Kadar fosfor yang ditetapkan pada standar kualitas kompos adalah > 1000 ppm hingga batas yang tidak ditentukan.

Kalium merupakan unsur hara makro yang sangat diperlukan tanaman dalam meningkatkan ketahanan terhadap penyakit tanaman tertentu dan perbaikan kualitas hasil tanaman. Hasil penelitian menunjukkan kadar kalium pada kompos perlakuan A sebesar 8609,61 ppm diikuti untuk perlakuan B 8605,14 ppm pada perlakuan $C$ sebesar 8857,40 ppm dan perlakuan D 8905,92 ppm. Setiap perlakuan memiliki perbedaan kadar kalium cukup kecil dimana perlakuan $\mathrm{D}$ unggul dengan memiliki kadar kalium tinggi dari semua perlakuan. Semua perlakuan memiliki kadar kalium yang masih berada dalam batas standar kualitas kompos yaitu > 2000 ppm menurut SNI 19-7030-2004.

\subsubsection{Analisis Unsur Mikro (Fe, Mn, Zn)Kompos}

Unsur hara mikro meliputi unsur besi $(\mathrm{Fe})$, magnesium $(\mathrm{Mg})$, seng $(\mathrm{Zn})$, mangan (Mn), kalsium (Ca) dan sulfur (S) berperan dalam memelihara keseimbangan hara dalam tanah (Sarno, 2008).Pada analisis kompos kotoran babi, unsur hara mikro yang diuji adalah unsur Fe, Mn dan Zn.

Hasil analisis untuk kandungan unsur mikro meliputi unsur besi (Fe), mangan (Mn) dan seng (Zn) pada empat perlakuan ditunjukkan dengan grafik pada Gambar 6. Zat besi (Fe) penting bagi pembentukan hijau daun (khlorofil),pembentukan zat karbohidrat, lemak, protein dan enzim. Kadar unsur Fe pada kompos kotoran babi pada masing-masing perlakuan memenuhi nilai standar yaitu $2,00 \%$. Perlakuan A memiliki kadar Fe sebesar 1,42\% diikuti perlakuan B 1,59\% kemudian perlakuan C $1,87 \%$ dan perlakuan D $1,64 \%$. Perlakuan $\mathrm{C}$ memiliki kadar Fe paling tinggi diantara tiga perlakuan lainnya. Hal ini disebabkan campuran bahan baku sayuran serta larutan MOL sayuran lebih mendominasi dimana sayuran seperti bayam dan kangkung mengandung zat besi yang cukup tinggi.

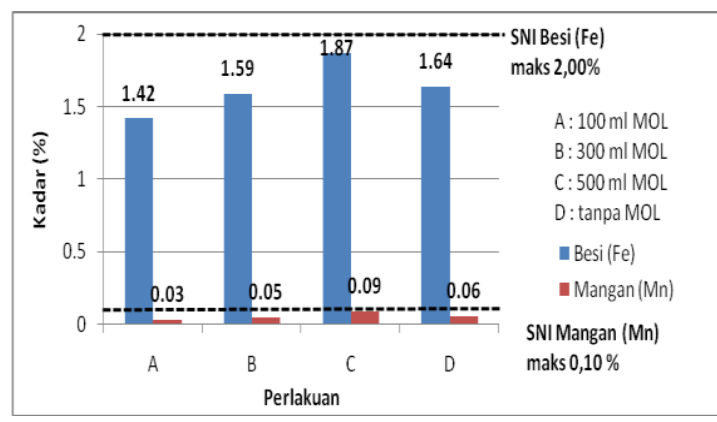

Gambar 6.

Grafik analisis unsur hara mikro Fe, $\mathrm{Mn}$ dan Zn kompos

Unsur hara mangan (Mn) penting untuk dapatmempertahankan kondisi warna hijau daunpada daun yang tua, memperlancar proses asimilasi dan merupakan komponen penting berbagai enzim (Mulyani, 2014). Hasil analisis menunjukkan kadar Mn pada semua perlakuan berada dalam batas standar yaitu $0,10 \%$ menurut SNI 19-70302004. Perlakuan D memiliki kadar Mn paling tinggi yaitu $0,09 \%$ diikuti perlakuan C $0,06 \%$ lalu perlakuan B $0,05 \%$ dan perlakuan A $0,03 \%$. Nilai kadar unsur hara Mn semua perlakuan memenuhi standar kualitas kompos.

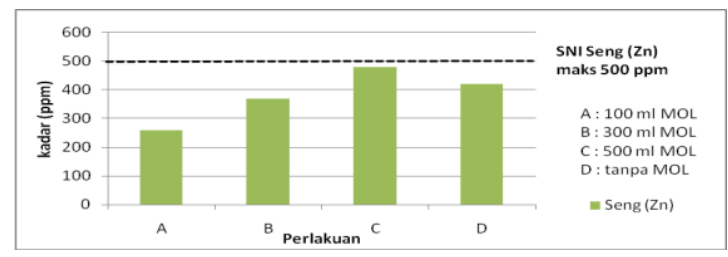

Gambar 7.

Grafik analisis unsur hara mikro Seng

( $\mathrm{Zn})$

Gambar 7 menunjukkan grafik analisis unsur hara mikro yaitu Zink atau seng (Zn) yang berperan dalam 
membantu pembentukan karbohidrat, klorofil, dan zat penumbuh akar (auksin) (Soeryoko, 2011). Data analisis menunjukkan kadar $\mathrm{Zn}$ paling tinggi diperoleh perlakuan $\mathrm{C}$ sebesar $480 \mathrm{ppm}$ diikuti perlakuan D sebesar 420 ppm lalu perlakuan B sebesar $370 \mathrm{ppm}$ dan perlakuan A sebesar 260 ppm. Nilai kadar Zn semua perlakuan masih dalam batas standar kualitas kompos yaitu maksimum 500 ppm.

\subsubsection{Derajat Keasaman atau pH Kompos}

Perubahan $\mathrm{pH}$ terjadi akibat aktivitas mikroorganisme selama proses pengomposan dapat dilihat pada grafik Gambar 8 yang menunjukkan grafik perubahan $\mathrm{pH}$ selama proses pengomposan dari keempat perlakuan. Awal proses pengomposan keempat perlakuan memiliki $\mathrm{pH}$ yang sama yaitu 7,0. Pada perlakuan A bahan baku dengan penambahan $100 \mathrm{ml}$ MOL nilai $\mathrm{pH}$ perlahan meningkat dari minggu ke1 hingga mencapai maksimum di minggu ke-3 menjadi 7,2. Kondisi $\mathrm{pH}$ mulai menurun di minggu ke-4 dan mengalami kestabilan di minggu ke-5 hingga ke-6 dimana $\mathrm{pH}$ menjadi 6,9 ditandai dengan pematangan kompos.Perlakuan B dengan penambahan $300 \mathrm{ml}$ MOL memiliki perubahan $\mathrm{pH}$ yang sama dengan perlakuan A.

Berbeda dari kedua perlakuan sebelumnya, perlakuan $\mathrm{C}$ dengan penambahan $500 \mathrm{ml}$ MOL mengalami peningkatan $\mathrm{pH}$ lebih cepat yaitu di minggu ke-2 sebesar 7,3. Hal ini disebabkan oleh proses dekomposisi mikroorganisme dalam bahan organik menghasilkan amonia dengan memecah ikatan senyawa menjadi nitrogen yang menyebabkan $\mathrm{pH}$ meningkat. Saat kondisi $\mathrm{pH}$ meningkat, amonia akan menyebar ke udara sehingga menghasilkan bau menyengat pada tumpukan bahan kompos. Selain bau menyengat, suhu kompos juga meningkat karena amonia menghasilkan panas pada tumpukan bahan kompos. Kondisi $\mathrm{pH}$ kembali menurun di minggu ke-3 pH disebabkan oleh berkurangnya aktivitas mikroorganisme dalam merombak bahan baku organik sehingga bau menyengat berkurang dan suhu juga mengalami penurunan. Pada tahap ini campuran bahan kompos mengalami proses pematangan kompos dan mulai stabil di minggu ke-4 dengan $\mathrm{pH}$ 6,8 menandakan kompos telah matang.

Perlakuan D tanpa penambahan MOL menunjukkan peningkatan $\mathrm{pH}$ yang lebih lambat dari ketiga perlakuan sebelumnya. Derajat keasaman $(\mathrm{pH})$ menunjukkan peningkatan di minggu ke-1 dan mencapai maksimum dalam jangka waktu lebih lama yaitu di minggu ke-4 sebesar 7,3. Pencapaian $\mathrm{pH}$ maksimum lebih lama disebabkan aktivitas mikroorganisme yang lambat dalam mengurai bahan organik kompos sehingga bahan kompos lama terurai. Oleh karena itu, proses pematangan kompos berlangsung lama pada perlakuan D yaitu pada minggu ke-6.

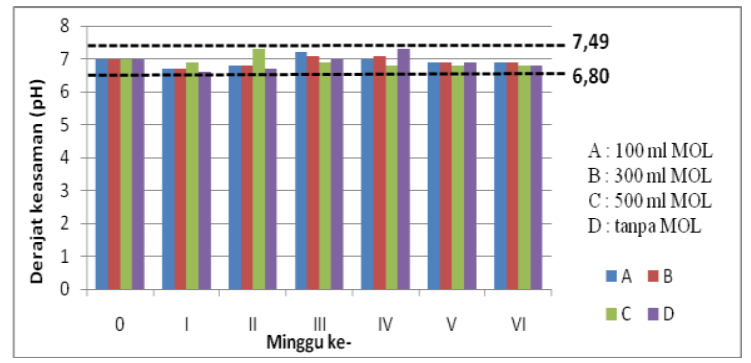

Gambar 8 .

Grafik perubahan $\mathrm{pH}$ selama proses pengomposan

\subsection{Pengaruh Penambahan MOL terhadap Waktu Pengomposan}

Kematangan kompos diperlukan untukmenentukan lama pengomposan. Oleh karena itu, diperlukan analisis pemantauan parameter suhu, $\mathrm{pH}$, warna serta bau.Uji parameter ini dilakukan 
setiap 3 hari sampai kompos menjadimatang.Perlakuan $\mathrm{C}$ dengan penambahan $500 \mathrm{ml}$ larutan MOL menunjukkan tumpukan bahan kompos mengalami peningkatan suhu paling cepat mulai minggu ke-1 $\left(38^{0} \mathrm{C}\right)$ hingga mencapai suhu maksimum di minggu ke-2 $\left(54^{0} \mathrm{C}\right)$. Suhu tumpukan bahan kompos mengalami peningkatan disebabkan oleh aktivitas mikroorganisme dalam merombak bahan organik kompos. Penambahan larutan MOL terbukti dapat meningkatkan jumlah mikroorganisme sehingga proses perombakan bahan organik lebih cepat. Proses pematangan kompos pada perlakuan $\mathrm{C}$ terjadi pada minggu ke-4 ditandai dengan suhu rata-rata akhir sebesar $28^{\circ} \mathrm{C}, \mathrm{pH}$ 6,8 dengan warna cokelat kehitaman dan bau menyerupai tanah.

Perlakuan A dengan penambahan MOL $100 \mathrm{ml}$ dan perlakuan $\mathrm{B}$ penambahan $300 \mathrm{ml}$ MOL mengalami pematangan kompos yang sama yaitu di minggu ke-5 sedangkan perlakuan D tanpa penambahan MOL mengalami pematangan kompos paling lama yaitu pada minggu ke-6. Perbedaan lama waktu pengomposan yang terjadi disebabkan jumlah mikroorganisme yang terdapat pada masing-masing perlakuan berbeda. Mikroorganisme yang terdapat dalam bahan baku kompos tumbuh dan beradaptasi secara alami sehingga memerlukan waktu pengomposan cukup lama daripada perlakuan dengan penambahan MOL. Penambahan MOL dalam dosis besar lebih efektif digunakan untuk mempercepat proses pengomposan, hal ini dapat dibandingkan dengan penelitian sebelumnya oleh Suyasa dan Panca Dewi (2008) bahwa proses komposting kotoran babi dengan campuran bahan (kotoran babi 70\%, jerami $13 \%$, ampas tahu $15 \%$, dolomit $2 \%$ ) memiliki waktu pematangan di minggu ke-6 sedangkan proses komposting campuran bahan baku kotoran babi (25\%), limbah sayuran (75\%) dengan penambahan $500 \mathrm{ml}$ MOL mampu mencapai proses pematangan di minggu ke-4.

Analisis kimia dari kompos matang pada perlakuan $\mathrm{C}$ dengan penambahan $500 \mathrm{ml}$ MOL memenuhi standar kualitas kompos menurut SNI 19-7030-2004. Hasil analisis yang diperoleh meliputi $\mathrm{C} / \mathrm{N}$ rasio $(16,30)$, kadar $\mathrm{N}$-total $(1,65$ $\%), \mathrm{P}$ tersedia (8043,02 ppm), K tersedia (8857,40 ppm), Fe (1,87\%), Mn (0,09 $\%) \mathrm{Zn}$ (480 ppm). Semua parameter kimia tersebut menunjukkan bahwa kompos kotoran babi dan limbah sayuran memiliki kualitas yang baik sesuai SNI 19-7030-2004 sehingga dapat digunakan sebagai pupuk organik dibidang pertanian.

\subsection{Efektivitas Kelayakan Usaha Pembuatan Kompos}

Menentukan nilai efektivitas produksi kompos bertujuan untuk menganalisis kelayakan usaha pembuatan kompos melalui perhitungan biaya dan manfaat. Perhitungan biaya dan manfaat diperoleh dari perbandingan antara biaya pendapatan dan biaya pengeluaran sehingga dapat ditentukan layak atau tidaknya suatu usaha untuk dikembangkan. Untuk menganalisis kelayakan suatu usaha maka digunakan salah satu jenisanalisis perhitungan ekonomi yaitu B/C rasio.Skema perincian total biaya produksi dapat dilihat pada Tabel 3. 
Tabel 3. Tabel perincian biaya produksi kompos

\begin{tabular}{|c|c|c|c|c|}
\hline $\begin{array}{l}\mathbf{N} \\
\mathbf{o}\end{array}$ & $\begin{array}{c}\text { Kompone } \\
\text { n }\end{array}$ & $\begin{array}{c}\text { Kuantita } \\
\text { s }\end{array}$ & $\underset{)}{\operatorname{Harga}}(\mathbf{R p}$ & $\begin{array}{c}\text { Total } \\
\text { Harga } \\
\text { (Rp) }\end{array}$ \\
\hline & $\begin{array}{c}\text { Bahan } \\
\text { baku }\end{array}$ & & & \\
\hline 1. & $\begin{array}{l}\text { Kotoran } \\
\text { babi }\end{array}$ & $25 \mathrm{~kg}$ & $\begin{array}{l}\mathrm{Rp} 400,- \\
\quad / \mathrm{kg}\end{array}$ & Rp 10.000,- \\
\hline 2. & $\begin{array}{l}\text { Limbah } \\
\text { sayuran } \\
\text { kol, } \\
\text { bayam, } \\
\text { kangkung, } \\
\text { sawi } \\
\text { mentimun }\end{array}$ & $75 \mathrm{~kg}$ & $\begin{array}{l}\mathrm{Rp} 100,- \\
/ \mathrm{kg}\end{array}$ & Rp 7.500,- \\
\hline \multirow[t]{3}{*}{3.} & $\begin{array}{l}\text { Larutan } \\
\text { MOL }\end{array}$ & 0,5 liter & $\begin{array}{l}\text { Rp 5.000,- } \\
\quad \text { /liter }\end{array}$ & Rp 2.500,- \\
\hline & \multicolumn{3}{|c|}{ SUB TOTAL BIAYA BAHAN } & $\begin{array}{c}\mathbf{R p} \\
20.000,- \\
\end{array}$ \\
\hline & \multicolumn{3}{|c|}{$\begin{array}{c}\text { Tenaga kerja (1 orang x } 10 \text { hari x Rp } \\
5.000,-)\end{array}$} & $\begin{array}{c}\text { Rp } \\
\mathbf{5 0 . 0 0 0 , -}\end{array}$ \\
\hline $\begin{array}{l}\mathbf{N} \\
\mathbf{0}\end{array}$ & Peralatan & $\begin{array}{c}\text { Kuantita } \\
\text { s }\end{array}$ & $\underset{)}{\operatorname{Harga}(\mathbf{R p}}$ & $\begin{array}{l}\text { TotalHarg } \\
\text { a (Rp) }\end{array}$ \\
\hline 1. & $\begin{array}{l}\text { Tong } \\
\text { Komposter }\end{array}$ & 1 & $\begin{array}{c}\mathrm{Rp} \\
80.000,-\end{array}$ & Rp 80.000,- \\
\hline 2. & $\begin{array}{l}\text { Gayung } \\
\text { plastik }\end{array}$ & 1 & Rp 3.000,- & Rp 3.000,- \\
\hline 3. & Sekop & 1 & $\begin{array}{c}\mathrm{Rp} \\
20.000,-\end{array}$ & Rp 20.000,- \\
\hline 4. & Timbangan & 1 & $\begin{array}{c}\mathrm{Rp} \\
50.000,-\end{array}$ & Rp 50.000,- \\
\hline 5. & Ayakan & 1 & $\begin{array}{c}\mathrm{Rp} \\
10.000,-\end{array}$ & Rp 10.000,- \\
\hline \multirow[t]{3}{*}{6.} & Pisau & 1 & Rp 5.000,- & Rp 5.000,- \\
\hline & \multicolumn{3}{|c|}{ SUB TOTAL BIAYA PERALATAN } & $\begin{array}{c}\mathrm{Rp} \\
168.000,-\end{array}$ \\
\hline & \multicolumn{3}{|c|}{$\begin{array}{c}\text { Penyusutan (10\% dari biaya } \\
\text { peralatan) }\end{array}$} & $\begin{array}{c}\mathrm{Rp} \\
16.800,-\end{array}$ \\
\hline
\end{tabular}

Sumber: Hasil observasi peternak babi, 2017

Analisis $\mathrm{B} / \mathrm{C}$ rasio membandingkan antara keuntungan dan biaya yang dikeluarkan. Keuntungan usaha pembuatan kompos diperoleh dari selisih antara penerimaan dan total biaya. Perincian berat total produksi kompos yang dihasilkan dalam kondisi basah adalah $100 \mathrm{~kg}$ dan akan mengalami penyusutan sebesar 5\% sehingga berat total produksi kompos menjadi $95 \mathrm{~kg}$. Analisis kelayakan produksi kompos kotoran babi dapat dihitung dengan analisis $\mathrm{B} / \mathrm{C}$ rasio yaitu perbandingan antara keuntungan dan biaya total produksi kompos kotoran babi. Penerimaan yang diperoleh dari produksi $95 \mathrm{~kg}$ kompos kotoran babi adalah:

$$
\begin{aligned}
& \text { penerimaan }=\text { jumlah produksi } x \text { harga kompos } \\
& =95 \mathrm{~kg} x \frac{1.500}{\mathrm{~kg}}=R p 142.500 \\
& \text { keuntungan }=\text { penerimaan }- \text { total biaya } \\
& =R p 142.500-R p 70.000 \\
& =R p 72.500 \\
& \frac{B}{C} \text { rasio }=\frac{\text { keuntungan }}{\text { biaya total produksi }} \\
& =\frac{72.500}{70.000}=1,04
\end{aligned}
$$

Hasil perhitungan $\mathrm{B} / \mathrm{C}$ rasio diperoleh 1,04 dimana nilai tersebut masuk dalam kriteria B/C rasio lebih dari 1,00 sehingga usaha produksi kompos kotoran babi dan limbah sayuran efektif dan layak dikembangkan.

\section{SIMPULAN DAN SARAN}

\subsection{Simpulan}

Dari hasil penelitian yang dilakukan dapat disimpulkan:

1. $\mathrm{C} / \mathrm{N}$ rasio optimal komposisi bahan baku kompos yang terdiri dari $25 \%$ kotoran babi dan $75 \%$ limbah sayuran (kol, sawi, kangkung, bayam, mentimun) adalah 38,95.

2. Penambahan MOL pada bahan baku kompos mempengaruhi waktu pematangan kompos. Semakin besar volume penambahan MOL semakin cepat proses pematangan kompos. Penambahan $500 \mathrm{ml}$ MOL pada bahan baku kompos mempercepat waktu pengomposan menjadi 4 minggu.

3. Kualitas kompos kotoran babi dan limbah sayuran dengan penambahan MOL memiliki kadar $\mathrm{C} / \mathrm{N}$ rasio $(16,30), \mathrm{N}$-total $(1,65 \%), \mathrm{P}$ tersedia (8043,02 ppm), K tersedia (8857,40 ppm), Fe (1,87\%), Mn (0,09\%) Zn (480 ppm) yang memenuhi standar SNI 19-7030-2004. 
4. Usaha produksi kompos kotoran babi dan limbah sayuran layak untuk dikembangkan dengan efektivitas kelayakan usaha kompos berdasarkan analisis $\mathrm{B} / \mathrm{C}$ rasio sebesar 1,04.

\subsection{Saran}

Berdasarkan simpulan dari penelitian ini, maka dapat disarankan:

1. Pada penelitian selanjutnya bagi akademisi dapat mengaplikasikan kompos kotoran babi dan limbah sayuran pada tanaman pertanian seperti bayam, cabai dan terong untuk mengetahui tingkat kualitas kompos terhadap biologis pertumbuhan tanaman serta mengurangi penggunaan pupuk anorganik.

2. Usaha pembuatan kompos disarankan menggunakan komposisi bahan yaitu $25 \%$ kotoran babi, $75 \%$ limbah sayuran dan penambahan $500 \mathrm{ml}$ MOL untuk memperoleh kualitas kompos yang baik. Petani/peternak juga disarankan untuk membentuk suatu kelompok usaha pembuatan kompos demi pengembangan usaha kompos kotoran babi dan limbah sayuran dipasaran.

3. Pemerintah disarankan untuk ikut berpartisipasi dalam penyediaan fasilitas peralatan untuk usaha pembuatan kompos seperti komposter serta peralatan yang dibutuhkan oleh kelompok usaha pembuatan kompos.

\section{DAFTAR PUSTAKA}

Badan Pusat Statistik. 2015. Kota Denpasar Dalam Angka 2016. Denpasar.

Darius. 2001. Perancangan Reaktor Kompos Skala Rumah Tangga.
Skripsi. Jurusan Teknologi Pertanian. Fakultas Pertanian Universiatas Padjadjaran. Jatinangor.

Hsieh, S.c. and C.E. Hsieh. 1990. The use oforganic matter in crop production. ASPAC Food and Fertilizer Technology Center. Extension Bulletin No. 315:1-18.

Mulyani, Happy. 2014. Buku Ajar dan Aplikasi Optimasi Perancangan Model Pengomposan. Jakarta: TIM.

Purwasasmita M. dan Kunia K. 2009. "Mikroorganisme Lokal Sebagai Pemicu Siklus Kehidupan dalam Bioreaktor Tanaman". Seminar Nasional Teknik Kimia IndonesiaSNTKI 2009. Bandung 19-20 Oktober 2009.

Rynk, R., M. van de Kamp, G.B. Willson, M.E. Singley, T.L. Richard, J.J. Kolega, F.R. Gouin, L. Laliberty Jr., D. Kay, D.W. Murphy, H.A.J. Hoitink, and W.F.

Brinton. 1992.On-Farm Composting Handbook. New York : The Northeast Regional Agricultural Engineering Service, Coorperative Extension.

Sarno. 2008. Tingkat Kesuburan Tanah.http://khairultamimi.student. umm.ac.id/2010/01/22/proposalpenelitian/. Diakses pada tanggal 20 September 2017.

Sihombing, D.T.H, 2006. Petunjuk Praktis Beternak Babi. Bogor: Fakultas Peternakan IPB. 
SNI. 2004. Standar Kualitas Kompos.http://www.pu.go.id/balitb ang/sni/buat\%20web/RSNI\%20CD/ ABSTRAKS/Cipta\%20Karya/PERS AMPAHAN/SPESIFIKASI/SNI\%2 019- 7030-2004.pdf.

Soeryoko, Hery. 2011. Tanaman Obat Terpopuler Penurun Hipertensi. Yogyakarta: Andi.

Suyasa, Budiarsa dan Panca Dewi. 2008. Pemanfaatan Kotoran Babi Melalui Komposting Dan Pengaruhnya Terhadap Pertumbuhan Lombok Rawit (Capsicum frutescens). Bumi Lestari Journal of Environment Vol 8, No.1

Waris, M dan Achmar, M. 2015. Analisis Kelayakan Usaha Pupuk Organik Kelompok Tani Sumber Tani Desa Sumber Anyar Kecamatan Mlandingan Kabupaten Situbondo. Fakultas Pertanian Universitas Abdurachman Saleh. Situbondo.

Widjajanto, D. W. dan Sumarsono. 2005. Pertanian Organik. Semarang: Universitas Diponegoro. 